\title{
Recent Advances in the Immunopathogenesis of Acinetobacter baumannii Infection
}

\author{
Louis de Léséleuc ${ }^{1}$ and Wangxue Chen ${ }^{1,2, *}$ \\ ${ }^{1}$ Institute for Biological Sciences, National Research \\ Council Canada, Ottawa, Ontario \\ ${ }^{2}$ Department of Biology, Brock University, \\ St. Catharines, Ontario \\ Canada
}

\section{Introduction}

Organisms belonging to the species Acinetobacter baumannii are capsulated coccobacillary, gram-negative bacteria. They can be found in the environment, will colonize various body tissues and food products and can persist on inanimate objects for a prolonged time period. Among the genus Acinetobacter, A. baumannii is the best described and most often associated with human disease and casualties. It is regarded as an opportunistic pathogen (1) and mostly targets susceptible hosts where it causes pneumonia, urinary tract infections, wound infections and meningitis. Over the last decade, we have witnessed a significant rise in the number and severity of cases of A. baumannii infections from hospital outbreaks as well as sporadic community-associated and wound-associated cases (2).

It is believed that the ability of A. baumannii to persist in the environment, notably by forming protective biofilms, as well as its remarkable spectrum of antibiotic resistance have allowed it to emerge as a particularly problematic human pathogen $(3,4)$. Although these attributes appear to explain the resilience of this microbe, one must remember that a large array of innocuous bacterial species, including non-pathogenic members of the Acinetobacter genus, can resist antibiotics and form biofilms. Hence, the question of why A. baumannii is such a successful and lethal pathogen becomes more pertinent. Does it display additional unique features in its interactions with the host that favour successful colonization or infection? This chapter will bring together recent research in an attempt to answer these questions. It will strive to be both informative and perhaps inspire new strategies to better control this pathogen.

\section{Clinical manifestations of $\boldsymbol{A}$. baumannii pneumonia}

The major risk factor for infection with A. baumannii, also seen as the one that increases the overall susceptibility of the host, is the use of an invasive procedure such as mechanical

${ }^{*}$ Corresponding Author 
ventilation during intensive care (5). Patients first become infected following colonization from the environment. Sources of contamination include surgical equipment, endotracheal or nasogastric tubes, catheters and previously colonized health care staff. The length of stay at the ICU has repeatedly been associated with increased risk of colonization and infection (5-7). Colonization is usually asymptomatic but will increase the likelihood of subsequent infection, which may proceed when the host natural barriers are weakened by trauma, surgery or other invasive procedures.

Respiratory tract infections constitute a major portal of entry leading to A. baumannii bacteremia and are almost always hospital-acquired (8). Positive blood cultures are not commonly recognized in patients with nosocomial pneumonia (8). However, pneumonia caused by this organism are significantly more frequently associated with bacteremia and result in higher mortality rates (up to $50 \%$ of cases) (8). The clinical manifestations of $A$. baumannii lung infection, both in patients and in animal models, match those of the typical bacterial pneumonia, with alveolar congestion, edema and leukocytic infiltrations. Extracellular bacteria can be readily identified and cultured from lung biopsies and postmortem samples (8). Hence, it is alleged that bacteremia and sepsis are in most cases the final causes of death, not asphyxia and hypoxemia caused by pneumonia per se, although comorbidity significantly contributes to mortality (9).

\section{Multidrug resistance and antibiotic treatment}

Acinetobacter baumannii has acquired resistance to many antibiotics over the last two decades (10) and the incidence of infections caused by multi-drug resistant strains of A. baumannii have significantly increased worldwide. This has coincided with the appearance of carbapenem-resistant A. baumannii strains in North America, Asia, South America, South Africa and Australia. The global dissemination of carbapenem-resistant strains of $A$. baumannii demonstrates the success of this pathogen to cause epidemic outbreaks (11). A. baumannii appears able to acquire antibiotic resistance through multiple mechanisms such as over-expression of bacterial efflux pumps, changes in cell wall channels (porins), acquisition of extended-spectrum $\beta$-lactamases, gene mutations and expression of certain enzymes that modify the metabolism of the antibiotic (reviewed in (12-17)). In addition, it is reported that the A. baumannii genome contains a "resistance island" with 45 resistance genes (18). A. baumannii can also rapidly acquire genetic entities for resistance, including some genes derived from other bacterial species (19). To date, A. baumannii strains have demonstrated resistance not only to $\beta$-lactams, aminoglycosides, fluoroquinolones, chloramphenicol, tetracycline, and rifampicin, but also to some relatively new antibiotics such as tigecycline, a novel broad-spectrum glycylcycline (20).

The emergence of multi- and pan-drug resistant A. baumannii strains clearly presents significant challenges to the clinical management of the infection. The antibiotic selection for those A. baumannii strains is very limited. Despite its potential toxicity, polymyxin B and E (colistin) are probably the most commonly used and effective antibiotics for the treatment of resistant strains of $A$. baumannii at present $(12,14-16,21-23)$. Other antibiotic candidates are tigecycline and imipenem $(14,21-24)$ but, as discussed above, resistance to tigecycline has developed in some $A$. baumannii strains (20). To combat the multidrug resistance of $A$. baumannii, it is also a common clinical practice to prescribe several antibiotics as a combination therapy although such practice remains controversial among the medical 
profession $(12,24)$. Although antibiotic resistance and clinical treatment are the most important aspects of the management of $A$. baumannii infection, this topic is out of the main scope of this chapter. Readers are referred to some recent excellent review articles on the details of antibiotic resistance mechanisms and the advances and challenges in the development of new therapeutics for the treatment of A. baumannii infections (12-17, 21-23).

\section{Experimental models of $\boldsymbol{A}$. baumannii pneumonia}

Many clinical cases of $A$. baumannii have been rigorously described and are very informative about the disease course, risk factors and the prevalence of antibiotic resistance and other genetic traits in the isolates. However, these studies are not experimental in nature and are based on retrospective analysis of hospital-based cases. Thus, they generally fail to establish a causal relationship between the attributes of a given isolate and disease transmissibility, severity and clinical course, which define virulence. Knowledge of virulence factors can help both identify potentially dangerous pathogens before they strike and help develop new methods of control or treatments. Unfortunately, to date, aside from antibiotic-resistance genes, few virulence factors have been identified in A. baumannii (Table 1), despite wide variation in the ability of different laboratory strains and clinical isolates to cause disease in experimental models $(25,26)$. In addition, although a number of host factors have been examined for their potential involvement in the control of A. baumannii, only a few have been shown to play a role in resistance to infection (Table 2).

\begin{tabular}{|c|c|c|c|c|}
\hline Contributing factors & Model & Route of infection & Readout & Reference \\
\hline LPS & Serum sensitivity & in vitro & $\begin{array}{l}\text { Resistance to normal } \\
\text { human serum }\end{array}$ & $(38)$ \\
\hline LPS & $\begin{array}{l}\text { Rat soft tissue } \\
\text { Human serum }\end{array}$ & $\begin{array}{l}\text { Subcutaneous } \\
\text { in vitro }\end{array}$ & \begin{tabular}{|l} 
Bacterial \\
growth/survival
\end{tabular} & (39) \\
\hline $\begin{array}{l}\text { Many genes and loci } \\
\text { including urease }\end{array}$ & $\begin{array}{l}\text { Caenorhabditis } \\
\text { elegans } \\
\text { Dictyostelium } \\
\text { discoideum }\end{array}$ & in vitro & $\begin{array}{l}\text { Killing, egg count } \\
\text { Plaque assay }\end{array}$ & $(34)$ \\
\hline$O m p A$ & A549 epithelial cells & in vitro & Adherence, apoptosis & $(42)$ \\
\hline OmpA & $\begin{array}{l}\text { A549 epithelial cells } \\
\text { Mouse }\end{array}$ & \begin{tabular}{|l|} 
in vitro \\
Intratracheal \\
\end{tabular} & \begin{tabular}{|l|} 
Invasion \\
Blood counts \\
\end{tabular} & $(43)$ \\
\hline PBP-7/8 & $\begin{array}{l}\text { Rat soft tissue } \\
\text { Rat pneumonia } \\
\text { Human serum }\end{array}$ & \begin{tabular}{|l} 
Subcutaneous \\
Intratracheal \\
in vitro
\end{tabular} & $\begin{array}{l}\text { Bacterial } \\
\text { growth/survival }\end{array}$ & $(46)$ \\
\hline Phospholipase D & $\begin{array}{l}\text { Human serum } \\
\text { Epithelial cells } \\
\text { Mouse }\end{array}$ & $\begin{array}{l}\text { in vitro } \\
\text { in vitro } \\
\text { Intranasal }\end{array}$ & $\begin{array}{l}\text { Growth } \\
\text { Invasion } \\
\text { Blood counts }\end{array}$ & (47) \\
\hline$p m r B$ & Mouse & Intraperitoneal & $\begin{array}{l}\text { Survival, microbial } \\
\text { growth in spleen }\end{array}$ & (35) \\
\hline$p t k$, epsA, capsule & $\begin{array}{l}\text { Human ascites fluid } \\
\text { Rat soft tissue }\end{array}$ & $\begin{array}{l}\text { in vitro } \\
\text { Subcutaneous }\end{array}$ & \begin{tabular}{|l} 
Bacterial \\
growth/survival
\end{tabular} & $(40)$ \\
\hline $\operatorname{Rec} A$ & $\begin{array}{l}\text { Macrophages } \\
\text { Mouse }\end{array}$ & $\begin{array}{l}\text { in vitro } \\
\text { Intraperitoneal }\end{array}$ & \begin{tabular}{|l|} 
Bacterial survival \\
Mortality
\end{tabular} & $(50)$ \\
\hline
\end{tabular}

Table 1. Identified virulence factors of A. baumannii 


\begin{tabular}{|l|l|l|l|l|l|}
\hline \multicolumn{1}{|c|}{$\begin{array}{c}\text { Resistance } \\
\text { factors }\end{array}$} & \multicolumn{1}{|c|}{ Model } & \multicolumn{1}{|c|}{$\begin{array}{c}\text { Route of } \\
\text { infection }\end{array}$} & \multicolumn{1}{|c|}{ Readout } & \multicolumn{1}{|c|}{$\begin{array}{l}\text { Noncontributing } \\
\text { factors }\end{array}$} & Reference \\
\hline $\begin{array}{l}\text { Acute-phase } \\
\text { response and } \\
\text { serum amyloid } \\
\text { A (negative } \\
\text { effect) }\end{array}$ & $\begin{array}{l}\text { Mouse, } \\
\text { turpentine } \\
\text { acute phase } \\
\text { model }\end{array}$ & Intranasal & $\begin{array}{l}\text { Lung bacterial } \\
\text { burdens }\end{array}$ & TNF-a & $(69)$ \\
\hline CD14, TLR4 & Mouse & Intranasal & Bacterial growth & TLR2 & $(65)$ \\
\hline Complement & $\begin{array}{l}\text { Human } \\
\text { serum }\end{array}$ & in vitro & $\begin{array}{l}\text { Bacterial } \\
\text { growth/survival }\end{array}$ & N/A & $(29,45)$ \\
\hline $\begin{array}{l}\text { NADPH } \\
\text { oxidase }\end{array}$ & Mouse & Intranasal & $\begin{array}{l}\text { Lung and spleen } \\
\text { bacterial burdens }\end{array}$ & NOS2 & $(71)$ \\
\hline Neutrophils & $\begin{array}{l}\text { Mouse, } \\
\text { systemic }\end{array}$ & Intraperitoneal & $\begin{array}{l}\text { Survival, bacterial } \\
\text { burden in organs }\end{array}$ & $\begin{array}{l}\text { Sex, strain, IL-17A, } \\
\text { KC }\end{array}$ & $(25)$ \\
\hline $\begin{array}{l}\text { Neutrophils, } \\
\text { MIP-2 }\end{array}$ & $\begin{array}{l}\text { Mouse, two } \\
\text { strains }\end{array}$ & Intranasal & $\begin{array}{l}\text { Lung and spleen } \\
\text { bacterial burdens }\end{array}$ & N/A & $(28,70)$ \\
\hline
\end{tabular}

Table 2. Identified host factors that are important in resistance to A. baumannii infection

The most widely used model for the study of A. baumannii virulence and host responses is based on the mouse (26-28). It has been exploited to study pneumonia as well as septicaemia caused by $A$. baumannii and was successful in identifying or validating both microbial virulence and host resistance factors. Overall, conventional mice (such as C57BL/6 and $\mathrm{BALB} / \mathrm{c}$ ) show relatively high resistance to respiratory infection with $A$. baumannii. Mice inoculated intranasally with up to $10^{8}$ viable A. baumannii develop an acute, self-limiting bronchopneumonia and infected mice generally clear the infection by 96 hours after inoculation (28). Moreover, the infection is usually limited to the respiratory tract with minimal systemic dissemination. As expected, treatment of mice with immunosuppressive drugs (such as cyclophosphamide) greatly exacerbate the infection and can convert an otherwise self-limiting infection into a lethal one (27). In addition, a rat model has been established and used to study both pneumonia and soft tissue injury (29). Human studies are so far limited to bactericidal assays using serum or ascites fluid and the use of human peripheral blood mononuclear cells and various epithelial cell lines (29-33). More basic in vivo models involving inhibition of Caenorhabditis elegans and Dictyostelium discoideum were employed for screening the virulence of multiple $A$. baumannii transposon insertional mutants (34). In many studies, more than one aspect of virulence was explored to generate a more complete picture.

\section{Virulence factors of $A$. baumannii}

One of the defining attributes of A. baumannii, both biologically and clinically, is its ability to resist a number of antibiotic classes. It is often debated whether antibiotic resistance genes can be considered virulence factors. On the one hand, they do contribute to the capacity of the pathogen to cause disease by resisting treatment. On the other hand, they do not directly affect the natural course of the infection and only play a role when an exogenous chemotherapeutic compound is administered. However, this distinction is blurred when that resistance to antibiotics impacts on virulence in the absence of the antibiotic. For instance it was reported that colistin-resistant $A$. baumannii isolates show a general lower 
fitness as assessed by animal mortality and bacterial burdens in organs (35). The mutation conferring antibiotic resistance was mapped to the $p m r B$ gene. The $p m r A B C$ operon mediates resistance to colistin and other polymyxins through modification of the lipid A portion of LPS (36). Polymyxins bind to LPS; resistance can occur by the complete loss of lipid A through disruption of the biosynthetic genes, yielding LPS-deficient, Gram-negative bacteria (37). LPS was identified in at least two independent studies as contributing to bacterial virulence. It was first found to be important for serum resistance whereas capsular polysaccharide was dispensable (38). This was recently reproduced and further investigated in a wound infection model where LPS was found to be important for bacterial growth and survival (39). Hence, it is not surprising that downregulation of LPS as a means to resist polymyxins will significantly impact the virulence of the organism and might explain the low prevalence of colistin resistance in clinical isolates (21).

While capsular polysaccharides may not be required for serum resistance, the capsule was shown to be a major contributor to virulence since the growth of capsule-deficient variants of A. baumannii was attenuated in human ascites fluid and in a wound infection model (40). Hence, it is evident that different virulence factors may be manifest at distinct stages and physiological locations of the infection. Another iteration of that concept is found with outer membrane protein A (AbOmpA), a porin-like protein of A. baumannii which appears to mediate multiple functions. This protein is homologous to OmpA proteins from Enterobacteria and outer membrane protein F (OprF) of Pseudomonas sp. (41). AbOmpA was reported to mediate cytotoxicity in human HEp-2 cells (32) and dendritic cells (33). It also mediates interaction and invasion of lung epithelial cells as wells as biofilm formation on abiotic surfaces $(42,43)$. Whether these in vitro events (attachment, invasion and apoptosis) are important for in vivo virulence is still uncertain. Moreover, AbOmpA was recently shown to play a role in iron metabolism, another feature that may impact virulence (44). In this regard, blood dissemination of OmpA-deficient bacteria was less pronounced in the mouse pneumonia model (43), suggesting that this protein influences virulence at one or many of the steps leading to bacteremia. One of these steps could be resistance to complement-mediated lysis (45).

Random transposon mutagenesis has the potential to provide a large amount of unbiased information about microbial virulence. In the last few years, this approach has been adapted for the study of A. baumannii physiology and pathogenesis. The first study reported by Michael G. Smith and colleagues (2007) combined high-density pyrosequencing with transposon mutagenesis and identified a number of putative pathogenicity loci (34). Their screen was based on inhibition of Dictyostelium and Caenorhabditis elegans by A. baumannii mutants. They reported that a large proportion of the pathogen's genome consisted of foreign DNA and found six islands associated with virulence. This underlined once more the ability of this pathogen to adapt and evolve by acquiring genetic material for antibiotic resistance and virulence. While informative, this screen was only a first step since the mutants were not complemented nor were they tested in a mammalian model. More recently, Russo et al. (2009) identified a putative low-molecular-mass penicillin-binding protein $7 / 8$ (PBP-7/8) as a virulence gene based on serum sensitivity and validated it in the rat models of pneumonia and soft tissue infection (46). PBP-7/8 affects cell morphology and is suspected to play a role in peptidoglycan synthesis and cell wall structure. A similar mutagenesis study using serum sensitivity as the readout and pneumonia as the validation step identified phospholipase D (PLD) as a bona fide virulence factor (47). Interestingly, PLD 
is also associated with virulence in Neisseria gonorrhoeae (48) and Corynebacterium pseudotuberculosis (49). Hence this enzyme could be used as a drug target for the design of novel antimicrobials.

Another bacterial enzyme that was recently shown to play a role in virulence is recA (50). This protein was found not only to mediate DNA repair in A. baumannii but also played a role in desiccation resistance, prevented killing inside macrophages as well as contributed to mouse lethality. It may be argued that such a pleotropic protein may not qualify as an authentic virulence factor, for which the defining function is to ensure development inside a live host independently of in vitro or environmental fitness. Nevertheless, recA shows promise as a specific antimicrobial target and its implication in virulence underscores the importance of a microorganism's DNA repair pathway in the battle between host and pathogen.

\section{Biofilm formation}

One of the hallmark features of the Acinetobacter genus is the ability to form biofilms on animate and inanimate surfaces. Biofilm formation is associated with bacterial persistence in chronic diseases and in the environment; however, it is not yet clear whether production of biofilms by A. baumannii is involved in virulence. A high level of heterogeneity has been observed between isolates with respect to biofilm formation, which could not be correlated with virulence or disease severity (51-53). Moreover, biofilm production and adherence to airway epithelial cells is also observed at similar frequencies in low virulence species of Acinetobacters (30). Nevertheless, biofilm formation may contribute to disease transmissibility by promoting survival of $A$. baumannii on surgical instruments, catheters and external body surfaces and enabling colonization. It is likely that a combination of features, including the various virulence factors, resistance to multiple antibiotics and general hospital infection management etc., make A. baumannii a successful clinical pathogen.

\section{Iron acquisition}

One last feature that is under scrutiny is the role of iron in A. baumannii pathogenesis. Iron is a redox metal essential to most life forms; it is a component of many enzymes and factors such as ribonucelotide reductase (54) and the cytochromes of the aerobic electron transport chain (55). Although abundant inside the body, iron is usually found in association with host macromolecules like heme and transferrin and, thus, is not readily available to bacteria. As a result, A. baumannii must develop strategies to capture and retain iron for its survival and growth. Using a proteomics-based approach, 58 proteins were found to be differentially expressed in A. baumannii in response to iron modulation, including AbOmpA (44). Although the importance of iron acquisition in pathogenesis has not been experimentally established, this suggests that $A$. baumannii has evolved sophisticated regulatory mechanisms to respond to iron deprivation which are meant to ensure survival in the host, where this metal is scarce.

The production of siderophores is one strategy used by the pathogen to grow under ironlimiting conditions $(56,57)$. Siderophores are small secreted molecules that bind iron with high affinity and can be taken up by bacteria as a way to scavenge trace iron from their surroundings. The siderophore produced by the A. baumannii type strain 19606 was termed "acinetobactin" (58). It is structurally related to the siderophore produced by Vibrio anguillarum and resembles catechol-type siderophores such as the enterobactins (59). Of note, A. baumannii 
isolates often differ in the structure of the siderophores and other iron acquisition factors they express (60). Another way that $A$. baumannii can acquire iron in the circulation is by utilizing hemin, a salt of heme generated from the breakdown of hemoglobin (61). Conversely, $A$. baumannii cannot use hemoglobin itself (61) and does not bind the iron transporter transferrin (57), unlike other gram-negative bacteria such as Neisseria and Moraxella (62).

The importance of iron metabolism was also supported by the discovery that a novel monobactam-class antibiotic, BAL30072, is particularly active against A. baumannii when tested against a panel of pathogenic gram-negative species $(63,64)$. BAL30072 is a catecholic $\beta$-lactam that binds iron and acts as a siderophore (63). Under iron-restricted conditions such as those encountered in vivo, the molecule would be taken up efficiently by the bacteria's siderophore capture machinery, acting as a Trojan horse to deliver the antibiotic inside the cell. Hence it is possible that a microorganism with a high avidity for iron and siderophores, such as A. baumannii, might be more easily targeted and killed by antibiotics of this class. As a bonus, resistance might appear by downregulating siderophore uptake but only at the expense of in vivo fitness.

\section{Host resistance factors}

Like $A$. baumannii virulence factors, host factors important for protection against $A$. baumannii infection are still largely unexplored. It is generally recognized that immunocompromised individuals are much more likely to become infected by A. baumannii, an opportunistic pathogen by most definitions (1). As such, the host innate immune system is generally successful in controlling the pathogen and that only when it fails does the infection progress, such as upon barrier disruption, severe stress or immunosuppressive drug treatment. Identification of host immune cells and molecules that are critical for resistance could help us better deal with these deadly infections by monitoring those factors and boosting or supplementing them as the need arises.

Infections with $A$. baumannii are characterised by an acute, rapid progression. The host appears to either control the infection or becomes overwhelmed by it. This implies that innate immunity plays a major role in the control of this pathogen. Indeed, CD14 and TLR4, members of the innate immune system and the LPS sensing pathway, have been shown to be essential for resistance to A. baumannii infection in a knockout mouse model, while TLR2 appeared to counteract the robustness of the induced innate immunity (65).

The importance of LPS sensing would be consistent with a strong, protective proinflammatory reaction against the pathogen. Paradoxically, trauma and postsurgical patients mounting a strong systemic acute-phase response are more susceptible to A. baumannii infections (66-68). Experimentally, an acute-phase response elicited in mice with turpentine or by direct injection of exogenous serum amyloid A protein reduced pulmonary inflammation and neutrophil migration during A. baumannii pneumonia (69). This treatment ultimately led to enhanced susceptibility in the mice. This phenomenon might explain part of the immunosuppression that permits the microbe to successfully infect hospital patients. Hence, control of A. baumannii probably requires a targeted and self-limiting inflammatory response.

Major effectors of the innate inflammatory response, neutrophils play a critical role in the control of A. baumannii infection, as would be expected when dealing with extracellular bacteria. They are rapidly recruited to the lungs after infection and contribute to its 
resolution. Early animal models of A. baumannii pneumonia used cyclophosphamide to render mice neutropenic $(24,27)$ which might have increased the magnitude of bacterial replication in vivo, although this was not addressed directly. The role of neutrophils was not formally investigated until much later when it was found that antibody-mediated depletion of neutrophils resulted in an acute lethal infection in mice that was associated with enhanced bacterial burdens in the lung and extrapulmonary dissemination to the spleen (28). Conversely, enhanced pulmonary recruitment of neutrophils by intranasal supplementation of the chemoattractant MIP-2 promoted clearance of the pathogen (28).

The importance of neutrophils and of the regulation of their trafficking was reinforced when it was shown that A/J mice are more susceptible to A. baumannii compared to C57BL/ 6 mice due to a delayed and weaker neutrophil recruitment (70). Strain differences in host responses are common and may lead to genetic studies uncovering novel resistance factors. However, the choice of strains, route of infection and measurements might be of prime importance since another study did not report differences between their experimental mouse strains when doing Intraperitoneal injections (25) while a third found differences in mortality but not in lung bacteriology when comparing three murine strains (27).

The role of neutrophils was further investigated at the molecular level to determine what effector functions were required for clearance of $A$. baumannii. It was found that NADPH phagocyte oxidase expressed in neutrophils played a major role in extrapulmonary dissemination of $A$. baumannii whereas the contribution of inducible nitric oxide synthase (NOS2) was minor (71). This is consistent with evidence that NOS2 may be predominantly restricted to the control of intracellular pathogens (72). Other factors suspected to play a role such as sex, IL-17A and the chemokine KC (CXCL1) were also ruled out (25). Still unresolved is the role of the lung macrophages and epithelial cells in the initial recognition of the pathogen and subsequent recruitment of neutrophils. Are these cell types and others involved in recruiting neutrophils to the site of infection? Is infection of epithelial cells essential for the translocation of the pathogen into the circulation? Many of the initial steps of $A$. baumannii infection remain unexplored.

In the bloodstream, A. baumannii would encounter other hurdles to infection and dissemination. Blood contains a number of innate immune components that can restrict bacterial growth and even kill a large proportion of infecting microorganisms. Human serum is bactericidal or bacteriostatic to most strains of $A$. baumannii and this was shown to be mediated by complement $(29,45)$. The alternative complement pathway is responsible for killing the bacteria $(45,51)$. Interestingly, serum resistance in some strains was explained by the binding of Factor $\mathrm{H}$, an inhibitor of this pathway, to A. baumannii outer membrane proteins, including AbOmpA (45). However, this is not a universal phenomenon since binding to Factor $\mathrm{H}$ was not observed in another set of serum-resistant isolates (51).

There is clearly a substantial amount of variability in both the serum sensitivity of the pathogen and the bactericidal activity of sera from different individuals $(38,73)$. This could be due to past exposures and the presence of circulating antibodies. Lifelong exposure to Acinetobacter species from the environment might confer some low level of immunity to the pathogen. Indeed, both active and passive immunization using an inactivated whole cell vaccine are very effective at preventing A. baumannii infection in mice (74). This could explain why blood from naïve mice does not show any inhibitory activity towards $A$. baumannii (unpublished observations) and would suggest that blood does not contain 
significant natural defences against the pathogen, a state that could prove detrimental to the susceptible, naïve host.

\section{Conclusion}

Acinetobacter baumannii presents an array of features that make it a particularly troublesome pathogen. Similar to other emerging gram-negative bacilli like Pseudomonas aeruginosa and Klebsiella pneumonia, its quick rise in the past decades is probably the result of an ability to rapidly evolve and acquire new genetic material for virulence and antibiotic resistance. The multidrug resistance of several isolates of $A$. baumannii can be traced back to multiple events including downregulation of porins, expression of drug-inactivating enzymes and target alterations (75). Furthermore, the ability of A. baumannii to form biofilms allows it to persist on abiotic surfaces, a first step in disease transmission. When it finds an appropriate niche, such as the lung, it rapidly multiplies and creates a localized infection or colonization. If this infection is not contained effectively because of treatment failure or ineffective host defense mechanism, bacteremia will rapidly progress which may prove fatal.

Fast-growing in nature and able to overwhelm host defences, A. baumannii has a limited but effective set of virulence factors. One of them, AbOmpA, appears to simultaneously mediate host cell invasion, serum resistance and iron uptake, three potential prerequisites to virulence. This protein could therefore be a prime candidate for therapies targeting virulence mechanisms. Phospholipase D and recA are other candidates with an even wider spectrum that could benefit treatments of other infections. Other strategies targeting iron acquisition by the microbe could also prove successful. On the host side, boosting the activity of innate immunity such as neutrophils, or at least maintaining their proper numbers and function, could help slow or halt the progress of the pathogen.

Given the wide variation in the clinical success, biofilm formation, disease pathogenesis and antibiotic resistance profiles of A. baumannii isolates, it is currently difficult to pinpoint which steps and factors are really essential for virulence and which merely modulate it. More research needs to be conducted to better understand pathogenesis, preferably in experimentally controlled conditions involving characterised hosts and bacteria. Given enough information, the ultimate goal would be to predict the course and outcome of the disease when encountering an unknown isolate, in order to take appropriate measures. Another benefit would be to identify new therapeutic targets to supplement and perhaps replace the shrinking arsenal of chemotherapeutic agents at our disposal.

\section{Acknowledgements}

We wish to thank our current and past laboratory members and collaborators for their contributions in Acinetobacter research project and thank Ms. Rhonda KuoLee for her assistance in the preparation of this manuscript.

\section{References}

[1] Bergogne-Berezin E, Towner KJ. Acinetobacter spp. as nosocomial pathogens: microbiological, clinical, and epidemiological features. Clin Microbiol Rev. 1996 Apr;9(2):148-65. 
[2] Van Looveren M, Goossens H. Antimicrobial resistance of Acinetobacter spp. in Europe. Clin Microbiol Infect. 2004 Aug;10(8):684-704.

[3] Go ES, Urban C, Burns J, Kreiswirth B, Eisner W, Mariano N, et al. Clinical and molecular epidemiology of acinetobacter infections sensitive only to polymyxin B and sulbactam. Lancet. 1994 Nov 12;344(8933):1329-32.

[4] Villers D, Espaze E, Coste-Burel M, Giauffret F, Ninin E, Nicolas F, et al. Nosocomial Acinetobacter baumannii infections: microbiological and clinical epidemiology. Ann Intern Med. 1998 Aug 1;129(3):182-9.

[5] Baran G, Erbay A, Bodur H, Onguru P, Akinci E, Balaban N, et al. Risk factors for nosocomial imipenem-resistant Acinetobacter baumannii infections. Int J Infect Dis. 2008 Jan;12(1):16-21.

[6] Jamulitrat S, Thongpiyapoom S, Suwalak N. An outbreak of imipenem-resistant Acinetobacter baumannii at Songklanagarind Hospital: the risk factors and patient prognosis. J Med Assoc Thai. 2007 Oct;90(10):2181-91.

[7] Lee SO, Kim NJ, Choi SH, Hyong Kim T, Chung JW, Woo JH, et al. Risk factors for acquisition of imipenem-resistant Acinetobacter baumannii: a case-control study. Antimicrob Agents Chemother. 2004 Jan;48(1):224-8.

[8] Magret M, Lisboa T, Martin-Loeches I, Manez R, Nauwynck M, Wrigge H, et al. Bacteremia is an independent risk factor for mortality in nosocomial pneumonia: a prospective and observational multicenter study. Crit Care. 2011 Feb 16;15(1):R62.

[9] Cisneros JM, Rodriguez-Bano J. Nosocomial bacteremia due to Acinetobacter baumannii: epidemiology, clinical features and treatment. Clin Microbiol Infect. 2002 Nov;8(11):687-93.

[10] Fournier PE, Richet H. The epidemiology and control of Acinetobacter baumannii in health care facilities. Clin Infect Dis. 2006 Mar 1;42(5):692-9.

[11] Higgins PG, Dammhayn C, Hackel M, Seifert H. Global spread of carbapenem-resistant Acinetobacter baumannii. J Antimicrob Chemother. 2010 Feb;65(2):233-8.

[12] Munoz-Price LS, Weinstein RA. Acinetobacter Infection. N Engl J Med. 2008 March 20, 2008;358(12):1271-81.

[13] Towner KJ. Acinetobacter: an old friend, but a new enemy. J Hosp Infect. 2009 Dec;73(4):355-63.

[14] Maragakis LisaÂ L, Perl TrishÂA M. Antimicrobial Resistance: Acinetobacter baumannii: Epidemiology, Antimicrobial Resistance, and Treatment Options. Clinical Infectious Diseases. 2008;46(8):1254-63.

[15] Gootz TD, Marra A. Acinetobacter baumannii: an emerging multidrug-resistant threat. Expert review of anti-infective therapy. 2008 Jun;6(3):309-25.

[16] Dijkshoorn L, Nemec A, Seifert H. An increasing threat in hospitals: multidrug-resistant Acinetobacter baumannii. Nature reviews. 2007 Dec;5(12):939-51.

[17] Gaynes R, Edwards JR. Overview of nosocomial infections caused by gram-negative bacilli. Clin Infect Dis. 2005 Sep 15;41(6):848-54.

[18] Fournier PE, Vallenet D, Barbe V, Audic S, Ogata H, Poirel L, et al. Comparative genomics of multidrug resistance in Acinetobacter baumannii. PLoS Genet. 2006 Jan;2(1):e7.

[19] Ribera A, Ruiz J, Vila J. Presence of the Tet M determinant in a clinical isolate of Acinetobacter baumannii. Antimicrob Agents Chemother. 2003 Jul;47(7):2310-2. 
[20] Navon-Venezia S, Leavitt A, Carmeli Y. High tigecycline resistance in multidrugresistant Acinetobacter baumannii. J Antimicrob Chemother. 2007 Apr;59(4):772-4.

[21] Livermore DM, Hill RL, Thomson H, Charlett A, Turton JF, Pike R, et al. Antimicrobial treatment and clinical outcome for infections with carbapenem- and multiplyresistant Acinetobacter baumannii around London. Int J Antimicrob Agents. 2009 Jan;35(1):19-24.

[22] Michalopoulos A, Falagas ME. Treatment of Acinetobacter infections. Expert Opin Pharmacother. 2010 Apr;11(5):779-88.

[23] Murray CK, Hospenthal DR. Treatment of multidrug resistant Acinetobacter. Current opinion in infectious diseases. 2005 Dec;18(6):502-6.

[24] Wolff M, Joly-Guillou ML, Farinotti R, Carbon C. In vivo efficacies of combinations of beta-lactams, beta-lactamase inhibitors, and rifampin against Acinetobacter baumannii in a mouse pneumonia model. Antimicrob Agents Chemother. 1999 Jun;43(6):1406-11.

[25] Breslow JM, Meissler JJ, Jr., Hartzell RR, Spence PB, Truant A, Gaughan J, et al. Innate Immune Responses to Systemic Acinetobacter baumannii infection in Mice: Neutrophils, but not IL-17, Mediate Host Resistance. Infect Immun. 2011 May 16.

[26] Eveillard M, Soltner C, Kempf M, Saint-Andre JP, Lemarie C, Randrianarivelo C, et al. The virulence variability of different Acinetobacter baumannii strains in experimental pneumonia. J Infect. 2010 Feb;60(2):154-61.

[27] Joly-Guillou ML, Wolff M, Pocidalo JJ, Walker F, Carbon C. Use of a new mouse model of Acinetobacter baumannii pneumonia to evaluate the postantibiotic effect of imipenem. Antimicrob Agents Chemother. 1997 Feb;41(2):345-51.

[28] van Faassen H, KuoLee R, Harris G, Zhao X, Conlan JW, Chen W. Neutrophils play an important role in host resistance to respiratory infection with Acinetobacter baumannii in mice. Infect Immun. 2007 Dec;75(12):5597-608.

[29] Russo TA, Beanan JM, Olson R, MacDonald U, Luke NR, Gill SR, et al. Rat pneumonia and soft-tissue infection models for the study of Acinetobacter baumannii biology. Infect Immun. 2008 Aug;76(8):3577-86.

[30] de Breij A, Dijkshoorn L, Lagendijk E, van der Meer J, Koster A, Bloemberg G, et al. Do biofilm formation and interactions with human cells explain the clinical success of Acinetobacter baumannii? PLoS One. 2010;5(5):e10732.

[31] March C, Regueiro V, Llobet E, Moranta D, Morey P, Garmendia J, et al. Dissection of host cell signal transduction during Acinetobacter baumannii-triggered inflammatory response. PLoS One. 2010;5(4):e10033.

[32] Choi CH, Lee EY, Lee YC, Park TI, Kim HJ, Hyun SH, et al. Outer membrane protein 38 of Acinetobacter baumannii localizes to the mitochondria and induces apoptosis of epithelial cells. Cell Microbiol. 2005 Aug;7(8):1127-38.

[33] Lee JS, Choi CH, Kim JW, Lee JC. Acinetobacter baumannii outer membrane protein A induces dendritic cell death through mitochondrial targeting. J Microbiol. 2010 Jun;48(3):387-92.

[34] Smith MG, Gianoulis TA, Pukatzki S, Mekalanos JJ, Ornston LN, Gerstein M, et al. New insights into Acinetobacter baumannii pathogenesis revealed by high-density pyrosequencing and transposon mutagenesis. Genes Dev. 2007 Mar 1;21(5):601-14. 
[35] Lopez-Rojas R, Dominguez-Herrera J, McConnell MJ, Docobo-Perez F, Smani Y, Fernandez-Reyes $\mathrm{M}$, et al. Impaired virulence and in vivo fitness of colistinresistant Acinetobacter baumannii. J Infect Dis. 2011 Feb 15;203(4):545-8.

[36] Arroyo LA, Herrera CM, Fernandez L, Hankins JV, Trent MS, Hancock RE. The pmrCAB operon mediates polymyxin resistance in Acinetobacter baumannii ATCC 17978 and clinical isolates through phosphoethanolamine modification of Lipid A. Antimicrob Agents Chemother. 2011 Jun 6.

[37] Moffatt JH, Harper M, Harrison P, Hale JD, Vinogradov E, Seemann T, et al. Colistin resistance in Acinetobacter baumannii is mediated by complete loss of lipopolysaccharide production. Antimicrob Agents Chemother. 2010 Decv;54(12):4971-7.

[38] Garcia A, Solar H, Gonzalez C, Zemelman R. Effect of EDTA on the resistance of clinical isolates of Acinetobacter baumannii to the bactericidal activity of normal human serum. J Med Microbiol. 2000 Nov;49(11):1047-50.

[39] Luke NR, Sauberan SL, Russo TA, Beanan JM, Olson R, Loehfelm TW, et al. Identification and characterization of a glycosyltransferase involved in Acinetobacter baumannii lipopolysaccharide core biosynthesis. Infect Immun. 2010 May;78(5):2017-23.

[40] Russo TA, Luke NR, Beanan JM, Olson R, Sauberan SL, MacDonald U, et al. The K1 capsular polysaccharide of Acinetobacter baumannii strain 307-0294 is a major virulence factor. Infect Immun. 2010 Sep;78(9):3993-4000.

[41] Gribun A, Nitzan Y, Pechatnikov I, Hershkovits G, Katcoff DJ. Molecular and structural characterization of the HMP-AB gene encoding a pore-forming protein from a clinical isolate of Acinetobacter baumannii. Curr Microbiol. 2003 Nov;47(5):434-43.

[42] Gaddy JA, Tomaras AP, Actis LA. The Acinetobacter baumannii 19606 OmpA protein plays a role in biofilm formation on abiotic surfaces and in the interaction of this pathogen with eukaryotic cells. Infect Immun. 2009 Aug;77(8):3150-60.

[43] Choi CH, Lee JS, Lee YC, Park TI, Lee JC. Acinetobacter baumannii invades epithelial cells and outer membrane protein A mediates interactions with epithelial cells. BMC Microbiol. 2008;8:216.

[44] Nwugo CC, Gaddy JA, Zimbler DL, Actis LA. Deciphering the iron response in Acinetobacter baumannii: A proteomics approach. J Proteomics. 2010 Jan 1;74(1):44-58.

[45] Kim SW, Choi CH, Moon DC, Jin JS, Lee JH, Shin JH, et al. Serum resistance of Acinetobacter baumannii through the binding of factor $\mathrm{H}$ to outer membrane proteins. FEMS Microbiol Lett. 2009 Dec;301(2):224-31.

[46] Russo TA, MacDonald U, Beanan JM, Olson R, MacDonald IJ, Sauberan SL, et al. Penicillin-binding protein $7 / 8$ contributes to the survival of Acinetobacter baumannii in vitro and in vivo. J Infect Dis. 2009 Feb 15;199(4):513-21.

[47] Jacobs AC, Hood I, Boyd KL, Olson PD, Morrison JM, Carson S, et al. Inactivation of phospholipase D diminishes Acinetobacter baumannii pathogenesis. Infect Immun. 2010 May;78(5):1952-62.

[48] Edwards JL, Apicella MA. Neisseria gonorrhoeae PLD directly interacts with Akt kinase upon infection of primary, human, cervical epithelial cells. Cell Microbiol. 2006 Aug;8(8):1253-71. 
[49] McNamara PJ, Bradley GA, Songer JG. Targeted mutagenesis of the phospholipase D gene results in decreased virulence of Corynebacterium pseudotuberculosis. Mol Microbiol. 1994 Jun;12(6):921-30.

[50] Aranda J, Bardina C, Beceiro A, Rumbo S, Cabral MP, Barbe J, et al. The Acinetobacter baumannii RecA protein in the repair of DNA damage, antimicrobial resistance, general stress response, and virulence. J Bacteriol. 2011 Jun 3.

[51] King LB, Swiatlo E, Swiatlo A, McDaniel LS. Serum resistance and biofilm formation in clinical isolates of Acinetobacter baumannii. FEMS Immunol Med Microbiol. 2009 Apr;55(3):414-21.

[52] Cevahir N, Demir M, Kaleli I, Gurbuz M, Tikvesli S. Evaluation of biofilm production, gelatinase activity, and mannose-resistant hemagglutination in Acinetobacter baumannii strains. J Microbiol Immunol Infect. 2008 Dec;41(6):513-8.

[53] Wroblewska MM, Sawicka-Grzelak A, Marchel H, Luczak M, Sivan A. Biofilm production by clinical strains of Acinetobacter baumannii isolated from patients hospitalized in two tertiary care hospitals. FEMS Immunol Med Microbiol. 2008 Jun;53(1):140-4.

[54] Brown NC, Eliasson R, Reichard P, Thelander L. Nonheme iron as a cofactor in ribonucleotide reductase from E. coli. Biochem Biophys Res Commun. 1968 Mar 12;30(5):522-7.

[55] Rainnie DJ, Bragg PD. The effect of iron deficiency on respiration and energy-coupling in Escherichia coli. J Gen Microbiol. 1973 Aug;77(2):339-49.

[56] Echenique JR, Arienti H, Tolmasky ME, Read RR, Staneloni RJ, Crosa JH, et al. Characterization of a high-affinity iron transport system in Acinetobacter baumannii. J Bacteriol. 1992 Dec;174(23):7670-9.

[57] Actis LA, Tolmasky ME, Crosa LM, Crosa JH. Effect of iron-limiting conditions on growth of clinical isolates of Acinetobacter baumannii. J Clin Microbiol. 1993 Oct;31(10):2812-5.

[58] Yamamoto S, Okujo N, Sakakibara Y. Isolation and structure elucidation of acinetobactin, a novel siderophore from Acinetobacter baumannii. Arch Microbiol. 1994;162(4):249-54.

[59] Dorsey CW, Tomaras AP, Connerly PL, Tolmasky ME, Crosa JH, Actis LA. The siderophore-mediated iron acquisition systems of Acinetobacter baumannii ATCC 19606 and Vibrio anguillarum 775 are structurally and functionally related. Microbiology. 2004 Nov;150(Pt 11):3657-67.

[60] Dorsey CW, Beglin MS, Actis LA. Detection and analysis of iron uptake components expressed by Acinetobacter baumannii clinical isolates. J Clin Microbiol. 2003 Sep;41(9):4188-93.

[61] Zimbler DL, Penwell WF, Gaddy JA, Menke SM, Tomaras AP, Connerly PL, et al. Iron acquisition functions expressed by the human pathogen Acinetobacter baumannii. Biometals. 2009 Feb;22(1):23-32.

[62] Beddek AJ, Schryvers AB. The lactoferrin receptor complex in Gram negative bacteria. Biometals. 2010 Jun;23(3):377-86.

[63] Mushtaq S, Warner M, Livermore D. Activity of the siderophore monobactam BAL30072 against multiresistant non-fermenters. J Antimicrob Chemother. 2010 Feb;65(2):266-70. 
[64] Page MG, Dantier C, Desarbre E. In vitro properties of BAL30072, a novel siderophore sulfactam with activity against multiresistant gram-negative bacilli. Antimicrob Agents Chemother. 2010 Jun;54(6):2291-302.

[65] Knapp S, Wieland CW, Florquin S, Pantophlet R, Dijkshoorn L, Tshimbalanga N, et al. Differential roles of CD14 and toll-like receptors 4 and 2 in murine Acinetobacter pneumonia. Am J Respir Crit Care Med. 2006 Jan 1;173(1):122-9.

[66] Ayan M, Durmaz R, Aktas E, Durmaz B. Bacteriological, clinical and epidemiological characteristics of hospital-acquired Acinetobacter baumannii infection in a teaching hospital. J Hosp Infect. 2003 May;54(1):39-45.

[67] Keen EF, 3rd, Robinson BJ, Hospenthal DR, Aldous WK, Wolf SE, Chung KK, et al. Incidence and bacteriology of burn infections at a military burn center. Burns. 2010 Jun;36(4):461-8.

[68] Caricato A, Montini L, Bello G, Michetti V, Maviglia R, Bocci MG, et al. Risk factors and outcome of Acinetobacter baumanii infection in severe trauma patients. Intensive Care Med. 2009 Nov;35(11):1964-9.

[69] Renckens R, Roelofs JJ, Knapp S, de Vos AF, Florquin S, van der Poll T. The acute-phase response and serum amyloid A inhibit the inflammatory response to Acinetobacter baumannii Pneumonia. J Infect Dis. 2006 Jan 15;193(2):187-95.

[70] Qiu H, KuoLee R, Harris G, Chen W. High susceptibility to respiratory Acinetobacter baumannii infection in $\mathrm{A} / \mathrm{J}$ mice is associated with a delay in early pulmonary recruitment of neutrophils. Microbes Infect. 2009 Oct;11(12):946-55.

[71] Qiu H, Kuolee R, Harris G, Chen W. Role of NADPH phagocyte oxidase in host defense against acute respiratory Acinetobacter baumannii infection in mice. Infect Immun. 2009 Mar;77(3):1015-21.

[72] Chakravortty D, Hensel M. Inducible nitric oxide synthase and control of intracellular bacterial pathogens. Microbes Infect. 2003 Jun;5(7):621-7.

[73] Liao CH, Sheng WH, Chen YC, Hung CC, Wang JT, Chang SC. Predictive value of the serum bactericidal test for mortality in patients infected with multidrug-resistant Acinetobacter baumannii. J Infect. 2007 Aug;55(2):149-57.

[74] McConnell MJ, Pachon J. Active and passive immunization against Acinetobacter baumannii using an inactivated whole cell vaccine. Vaccine. 2010 Dec 10;29(1):1-5.

[75] Gootz TD. The global problem of antibiotic resistance. Crit Rev Immunol. 2010;30(1):79-93. 


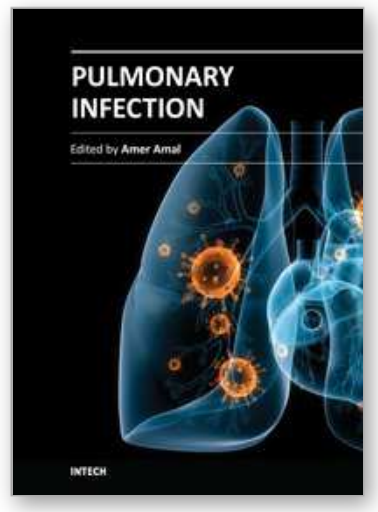

\author{
Pulmonary Infection \\ Edited by Dr. Amer Amal
}

ISBN 978-953-51-0286-1

Hard cover, 128 pages

Publisher InTech

Published online 14, March, 2012

Published in print edition March, 2012

Pulmonary infections are notorious in causing considerable morbidity and mortality. Caused by bacteria, viruses or fungi, respiratory infections require distinct knowledge of recent advances in pathogenesis. Progress in the understanding of immunopathogenesis of Acinetobacter baumannii infection will explain how an atypical organism establishes infection. The chapter regarding pulmonary nontuberculous mycobacterial infections in the State of Para depicts a unique study in an endemic region for tuberculosis in North of Brazil. The diagnosis and treatment of latent tuberculosis is a formidable challenge. Thus, new developments in diagnosis and treatment of latent tuberculosis are included in this book. Challenging in their diagnosis, nontuberculous mycobacterial pulmonary diseases require special education for management. The problems of respiratory infections in the immunocompromised host are increasing in numbers and in resilience to treatment. Therefore, the chapter describing the host immune responses against pulmonary fungal pathogens comes as a necessary section in this book. The insight brought forth from this book can be valuable for both clinicians and scientists.

\title{
How to reference
}

In order to correctly reference this scholarly work, feel free to copy and paste the following:

Louis de Léséleuc and Wangxue Chen (2012). Recent Advances in the Immunopathogenesis of Acinetobacter baumannii Infection, Pulmonary Infection, Dr. Amer Amal (Ed.), ISBN: 978-953-51-0286-1, InTech, Available from: http://www.intechopen.com/books/pulmonary-infection/recent-advances-in-the-immunopathogenesis-ofacinetobacter-baumannii-infection

\section{INTECH}

open science | open minds

\section{InTech Europe}

University Campus STeP Ri

Slavka Krautzeka 83/A

51000 Rijeka, Croatia

Phone: +385 (51) 770447

Fax: +385 (51) 686166

www.intechopen.com

\section{InTech China}

Unit 405, Office Block, Hotel Equatorial Shanghai

No.65, Yan An Road (West), Shanghai, 200040, China 中国上海市延安西路65号上海国际贵都大饭店办公楼 405 单元

Phone: +86-21-62489820

Fax: +86-21-62489821 
(C) 2012 The Author(s). Licensee IntechOpen. This is an open access article distributed under the terms of the Creative Commons Attribution 3.0 License, which permits unrestricted use, distribution, and reproduction in any medium, provided the original work is properly cited. 